\title{
Desafios da Adesão ao Programa de Educação Corporativa
}

Autores: COSTA, Roberta da Silva Costa; LOPES, Flavia Freitas de Paula.

\section{Introdução}

O Programa de Educação Corporativa do Hospital Regional de Cotia tem como objetivo promover condições para desenvolvimento do processo de ensino-aprendizagem, atualização, qualificação, inserção de novas práticas profissionais e atividades que potencializem os sujeitos ampliando o conhecimento e aprimorando habilidades. Porém, mesmo depois de mais de cinco anos de implantação, a participação dos colaboradores nos treinamentos institucionais era aquém do esperado, impactando negativamente resultados planejados.

\section{Objetivo}

Melhorar a adesão aos treinamentos institucionais, para o alcance de melhores resultados assistenciais.

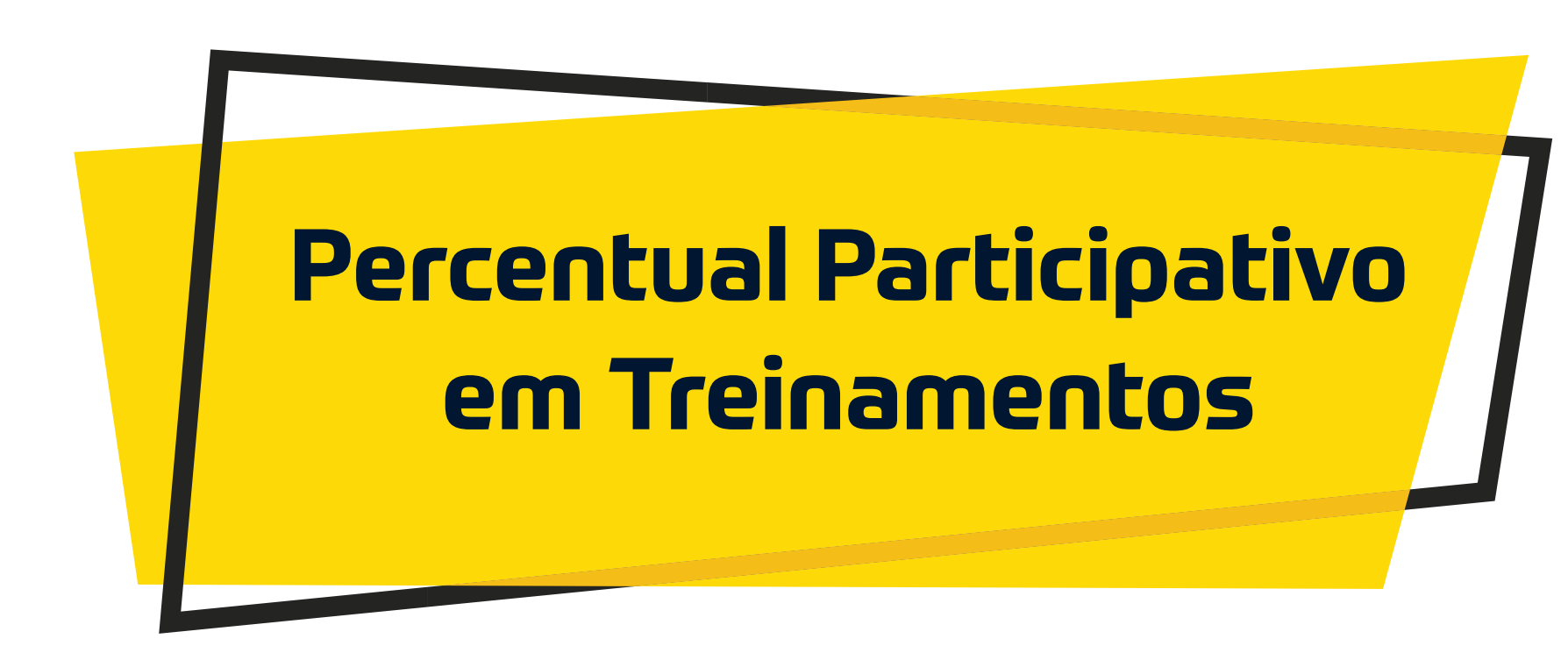

\section{Método}

Inicialmente foram levantadas as principais dificuldades encontradas para a baixa adesão aos treinamentos. Conhecidas estas dificuldades, ações foram tomadas para tentar saná-las:

- Sensibilizar os gestores quanto ao impacto dos treinamentos na melhoria da qualidade da assistência prestada;

- Planejar os treinamentos com foco nos objetivos e público alvo;

- Rever as metodologias, utilizando metodologias ativas e de gamificação, compatíveis com os conteúdos e público alvo;

- Implantar a Matriz Anual de Treinamentos;

- Definir o público alvo nominalmente e monitorar a adesão dos participantes individualmente.

2013

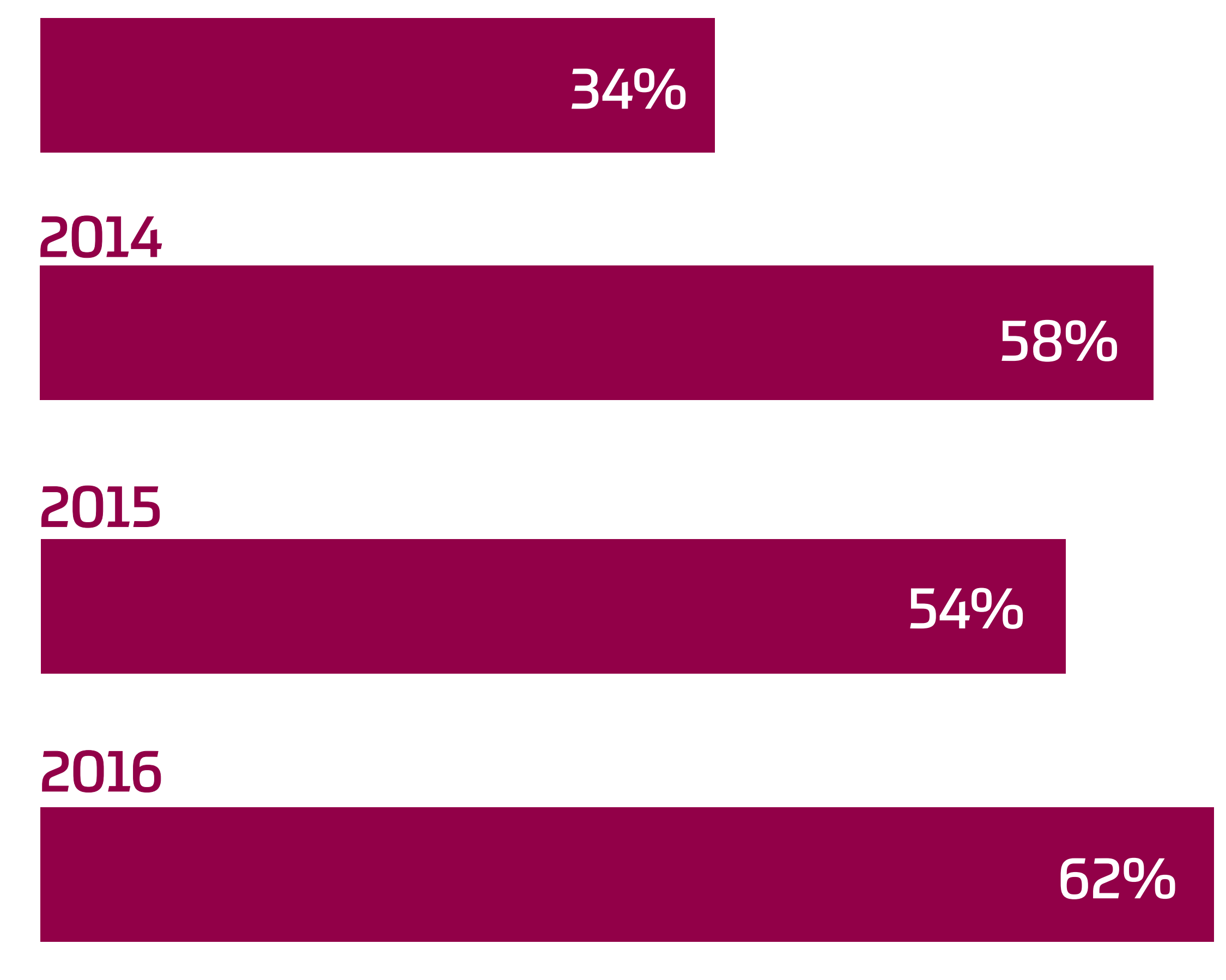

2017

2018

\section{Conclusão}

As ações foram realizadas ao longo dos últimos anos, observando-se uma melhor gradativa chegando, em 2018, a uma adesão participativa de 86\%. (Gráfico I). Esta abordagem contribuiu para a melhoria da qualidade e segurança da assistência prestada ao paciente.

\section{sẵo}

NORMAABNT NBR ISO 10015.2001. Gestão da qualidade Diretrizes para treinamento. 